\title{
Z DZIEJÓW OSADNICTWA W WIDLACH WARTY I LISWARTY I PRZEMIAN LUDNOŚCIOWYCH NA PRZYKŁADZIE PARAFII WĄSOSZ
}

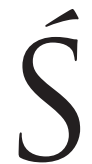
lady osadnictwa w widłach Warty i Liswarty wskazują na zasiedlenie tych obszarów już w epoce brązu. W latach 50. i 60. XX w. archeolodzy prowadzili intensywne badania na tym obszarze ${ }^{1}$. Jednak nie tylko wykopaliska archeologiczne dostarczają cennych informacji o zasiedleniu tych terenów. Na podstawie zachowanych ksiąg metrykalnych z parafii Wąsosz można prześledzić zachodzące na tym obszarze procesy osadnicze aż do XX w. i zmiany w strukturze ludności.

\section{Położenie geograficzne}

W średniowieczu w widłach Warty i Liswarty utworzono parafię Wąsosz (dziś parafia Wąsosz Górny w archidiecezji częstochowskiej, w województwie śląskim). W jej granicach znalazł się obszar leżący na Wyżynie Śląsko-Krakowskiej, która składa się z Wyżyny Śląskiej, Wyżyny Woźnicko-Wieluńskiej i Wyżyny Krakowsko-Częstochowskiej². Wyżyna Woźnicko-Wieluńska dzieli się na mniejsze jednostki zwane mezoregionami, m.in. Wyżynę Wieluńską, Obniżenie Liswarty-Prosny, Próg Herbski i Obniżenie Krzepickie ${ }^{3}$.

\footnotetext{
${ }^{1}$ K. Godłowski, Badania w Wąsoszu Górnym, pow. Kłobuck, „Biuletyn Śląskiego Instytutu Naukowego" 1959, nr 10, s. 24-25; tenże, Sprawozdanie z badań wykopaliskowych przeprowadzonych wr. 1959 w Wąsoszu Górnym, pow. Kłobuck, „Biuletyn Śląskiego Instytutu Naukowego” 1962, nr 32, s. 72-74; tenże, Sprawozdania z badań wykopaliskowych w dorzeczu Liswarty w latach 1965-1966, „Sprawozdania Archeologiczne”, t. 20, 1969, s. 167-168, 182; J. Piaskowski, Metaloznawcze badania wyrobów żelaznych z osady w Wasoszu Górnym, pow. Kłobuck, „Wiadomości Archeologiczne”, t. 28, 1962, z. 3, s. 218-230; B. Ginter, Osadnictwo mezolityczne w rejonie górnej Warty, „Światowit”, t. 30, 1969, s. 190-191; M. Gedl, B. Ginter, K. Godłowski, Pradzieje i wczesne średniowiecze dorzecza Liswarty, cz. 1, Katowice 1970, cz. 2, Katowice 1971.

${ }^{2}$ J. Kondracki, Geografia regionalna Polski, Warszawa 2001, s. 39.

${ }^{3}$ Tamże, s. 248-249.
} 
Wyżyna Wieluńska rozciąga się między Wieluniem i Częstochową i stanowi część płyty górnojurajskiej dochodzącej do okolic Krakowa. Ma ona ok. 1440 km² powierzchni. Rozcinają ją doliny rzeczne Warty i Liswarty z dopływami Biała Oksza i Kocinka. Średnie wysokości terenu wahają się między 220 a $280 \mathrm{~m}$ n.p.m. Skały podłoża są pochodzenia akumulacyjnego i tektonicznego. Są one zbudowane ze skał jury środkowej i górnego triasu mniej odpornych na erozję niż wapienie górnojurajskie. W podłożu wapiennym występują leje i szczeliny pochodzenia krasowego ${ }^{4}$.

Uczeni wydzielili na obszarze Wyżyny Wieluńskiej trzy mikroregiony: Wysoczyznę Wieluńską, Wysoczyznę Działoszyńsko-Lindowską i Równinę Kłobucką zwaną także Pagórami Kłobuckimi. Wysoczyzna Wieluńska stanowi północno-zachodnią część Wyżyny Wieluńskiej i dochodzi do 265 m wysokości n.p.m. Jej północną granicą jest próg denudacyjny warunkowany uskokiem wieluńsko-siemkowickim. Od wschodu granica przebiega doliną Warty, od południa martwą doliną między Wartą a Prosną. Jest ona regionem rolniczym o przeważnie gliniastych glebach. Wysoczyzna Działoszyńsko-Lindowska rozciąga się po obu stronach działoszyńskiego przełomu Warty aż do doliny Liswarty. Północna jej część wewnątrz łuku Warty jest lesista. Występują tutaj kamieniołomy i wapienniki. Równina Kłobucka, czyli Pagóry Kłobuckie, są pojedynczymi wapiennymi wzniesieniami, pomiędzy którymi występują zasypane piaskami obniżenia. Głównymi ośrodkami miejskimi na Wyżynie Wieluńskiej są Wieluń, Działoszyn i Kłobuck ${ }^{5}$.

Parafia Wąsosz leży na Wysoczyźnie Działoszyńsko-Lindowskiej. Na jej terenie występuje przeważnie krajobraz równinny z niewielkimi wydmami. Przepływa przez nią Warta i częściowo jej dopływ Liswarta oraz Kocinka. Tereny są tu częściowo podmokłe i zalesione ${ }^{6}$.

Pod względem klimatycznym obszar parafii Wąsosz znajduje się w strefie klimatu umiarkowanego. Według podziału E. Romera, tereny te leżą częściowo w regionie klimatycznym wyżyn środkowych a częściowo wielkich dolin ${ }^{7}$. Obszar ten jest zaliczany do łódzkiej dzielnicy rolniczo-klimatycznej, która jest strefą przejściową między Krainą Wielkich Dolin a pasmem starych gór i wyżyn. Jej granice wyznaczały miejscowości: Głogów, Kluczbork, Krzepice, Włoszczowa, Skarżysko-Kamienna, Radom, Głowno, Głogów ${ }^{8}$.

${ }^{4}$ Tamże, s. 249; R. Rosin, Ziemia wieluńska w XII-XVI w. Studia z dziejów osadnictwa, Łódź 1961, s. 42-43.

${ }^{5}$ J. Kondracki, Geografia regionalna ..., s. 249-250.

${ }^{6}$ Tamże, s. 162.

7 J. Paszyński, T. Niedźwiedź, Klimat, [w:] Geografia Polski. Środowisko przyrodnicze, red. L. Starkel, Warszawa 1999, s. 340, ryc. 231; E. Romer, Regiony klimatyczne Polski, Wrocław 1949, s. 20, mapa 2: Regiony klimatu.

${ }^{8}$ R. Rosin, Ziemia wieluńska..., s. 58. 


\section{Rozwój osadnictwa na terenie parafii}

Parafia Wąsosz była parafią dość rozległą terytorialnie. W okresie przedrozbiorowym miejscowości należące do niej były położone na przestrzeni ok. jednej mili, czyli ok. 7,5 km na zachód od kościoła zlokalizowanego niedaleko brzegów Warty9 . Pod koniec XVIII w. do parafii przyłączono wieś Zawady, leżącą po drugiej stronie rzeki Liswarty i należącą wcześniej do parafii Kłobuck w diecezji krakowskiej ${ }^{10}$. Nastąpiło to przed 1787 r., gdyż wtedy już wieś należała do parafii Wąsosz ${ }^{11}$. W XIX w. na tym obszarze powstały nowe osady położone nawet w odległości ok. $10 \mathrm{~km}$ od świątyni, np. Smolarze. Teren parafii uległ zmniejszeniu w następstwie jej podziału i erygowaniu w 1957 r. nowej parafii w Popowie.

Przez długie wieki na terenie parafii Wąsosz były tylko trzy wioski: Wąsosz, Popów i Więcki. Wąsosz wzmiankowano po raz pierwszy w źródłach ok. poł. XIII w. W 1250 r. pojawiła się nazwa Venruse, którą część badaczy utożsamia z Wąsoszem, choć wydawca dokumentu, w którym ta nazwa występuje, kojarzył ją z raczej z miejscowością Wierischau (Wieruszów) w powiecie świdnickim. Miejscowość była wsią królewską i należała najpierw do starostwa krzepickiego a potem brzeźnickiego. W ciągu wieków wieś przechodziła różne koleje losu. Dobra królewskie w Wąsoszu, wraz z całym starostwem brzeźnickim, przekazano paulinom jasnogórskim na utrzymanie tamtejszej twierdzy na sejmie, 1 lutego 1717 r. Król August II Sas potwierdził nadanie 17 listopada 1718 r. Zakonnicy zarządzali nimi aż do rozbiorów. Po rozbiorach, aż do uwłaszczenia w 1864 r., Wąsosz był wsią rządową i należał do klucza dóbr rządowych Pajęczno ${ }^{12}$.

\footnotetext{
${ }^{9}$ Archiwum Diecezjalne we Włocławku (dalej: ADWł.,), sygn. Akta Archidiecezji Gnieźnieńskiej (dalej: AAG) Wizytacja (dalej: Wiz.) 73, s. 318.

${ }^{10}$ ADWł., sygn. AAG Wiz. 93, s. 165.

${ }^{11}$ Archiwum Archidiecezji Częstochowskiej im. ks. Walentego Patykiewicza (dalej: AACz.), sygn. Księgi Parafialne (dalej: KP) 313, s. 5.

${ }^{12}$ Archiwum Jasnogórskie, Dyplomy sygn. 483; Urkundensammlung zur Geschichte des Fürstenthums Oels bis zum Aussterben der Piastischen Herzogslinie. Hrsg. W. Haeusler. Wrocław 1883, s. 85; W. Patykiewicz, Chronologia parafii diecezji częstochowskiej, „Częstochowskie Wiadomości Diecezjalne (dalej: CzWD), 40(1966), s. 68; Lustracja województw wielkopolskich i kujawskich 1616-1620, cz. 1, wyd. Z. Górski, R. Kabaciński, J. Pakulski, Wrocław-Warszawa-Kraków 1994, s. 174-175; Lustracja województw wielkopolskich i kujawskich 1628-1632, cz. 2: Województwo sieradzkie, wyd. Z. Guldon, Wrocław-Warszawa-Kraków 1969, s. 114; Lustracja województw wielkopolskich i kujawskich 1659-1665, cz. 2: Województwa sieradzkie, tęczyckie, brzesko-kujawskie i ziemia dobrzyńska, wydali Z. Górski, J. Pakulski, A. Tomczak, Torun 1996, s. 47; Lustracja województwa krakowskiego 1789, cz. 2: Powiat lelowski oraz starostwo kłobuckie i brzeźnickie, wyd. A. Falniowska-Gradowska, I. Rychlikowa, Wrocław-Warszawa-Kraków 1963, s. 593-594; Tabella miast, wsi i osad Królestwa Polskiego z wyrażeniem ich położenia i ludności, alfabetycznie ułożona w Biórze Kommissyi Rząowey Spraw Wewnętrznych i Policyi, t. 2: M-Z, Warszawa 1827, s. 156; Wasosz, [w:] Słownik geograficzny Królestwa Polskiego i innych krajów stowiańskich, t. 13, red. F. Sulimierski, B. Chlebowski, W. Walewski, Warszawa 1893, s. 177; D. Złotkowski, Udział zakonu ojców paulinów w życiu spoteczno-politycznym Rzeczypospolitej w XVIII wieku, Częstochowa 1994, s. 40.
} 
Popów wspomniano pośrednio po raz pierwszy w 1395 r. Najpierw był wsią królewską, potem szlachecką, a ostatecznie należał do uposażenia klasztoru kanoników regularnych w Krzepicach. Po rozbiorach dobra klasztorne skonfiskowały władze pruskie i odtąd, aż do uwłaszczenia chłopów w 1864 r. był wsią rządową i wchodził w skład dóbr rządowych Iwanowice ${ }^{13}$.

Więcki wspomniano po raz pierwszy 4 stycznia 1445 r. przy okazji Mikołaja z Więcek, herbu Osmoróg. Przez dziesięciolecia, do uwłaszczenia w 1864 r., miejscowość był wsią szlachecką należącą do kilku właścicieli jednocześnie. Od nazwy miejscowości jej posiadacze przyjmowali nazwisko Więckowski. Z Więcek pisali się także Więckowscy określani przydomkiem Trixa występujący w źródłach parafialnych do XVIII w. W XVII-XIX w. właścicielami części wsi byli także przedstawiciele rodziny Rogalińskich, Rychłowskich, Święcickich, Buczyńskich i Tyxińskich ${ }^{14}$.

Na początku XVI w. wymieniono na terenie parafii Wąsosz trzy wsie: Wąsosz (łac. Vansosche, pol. Wąsosze), Więcki (łac. Vyaczky, pol. Więckowy, Więcki) i Popów (łac. Popow) ${ }^{15}$. Pod koniec XVII w. wymieniono również tylko te trzy wsie $^{16}$. Podobnie było w kościelnych aktach wizytacyjnych z 1712 r. $^{17}, 1729$ r. $^{18}$ i 1744 r. ${ }^{19}$ oraz ok. 1763 r. ${ }^{20} \mathrm{O}$ kolejnych osadach wspomniano dopiero w wizytacji w 1779 r. Poza tymi trzema największymi wsiami wspomniano także o pustkowiach Wąsosza ${ }^{21}$.

${ }^{13}$ Archiwum Główne Akt Dawnych w Warszawie (dalej: AGAD), Księgi podkomorskie wieluńskie, sygn. 7, k. 50; Joannis Dlugosz senioris canonici cracoviensis Liber beneficiorum dioecesis Cracoviensis nunc primum e codice autographo editus, t. 2: Ecclesiae parochiales, ed. A. Przeździecki, Kraków 1863-1864, s. 212; Popów, [w:] Stownik geograficzny Królestwa Polskiego i innych krajów stowiańskich, t. 8, red. F. Sulimierski, B. Chlebowski, W. Walewski, Warszawa 1887, s. 795; Tabella miast..., t. 2, s. 109.

${ }^{14}$ Zapiski herbowe $z$ dawnych ksiag ziemskich przechowywanych $w$ archiwach radomskiem $i$ warszawskiem, zebrał K. Potkański. „Archiwum Komisji Historycznej”, t. 3, Kraków 1886, nr 89, 91, s. 141-142; ADWł., sygn. AAG Akta Konsystorza Wieluńskiego (dalej: A. Kons. Wiel.) 2 (1489), k. 10; T. Stolarczyk, Szlachta wieluńska od XIV do połowy XVI wieku, Wieluń 2005, s. 201; AACz., sygn. KP 49, s. 19; AACz., sygn. Księgi Metrykalne (dalej: KM) 1151, s. 20; ADWł., sygn. AAG Wiz. 17, k. 33v; E. Szklarska, Rychłowski Stanisław h. Nałęcz (zm. 1727/1728), [w:] Polski słownik biograficzny (dalej: PSB), t. 33, Wrocław 1991-1992, s. 392-393; AACz., sygn. KM 1152, (mortuorum), s. 7; Archiwum Parafii Wąsosz Górny (dalej: APWąsosz), brak sygn. Liber metrices baptisatorum Ecclesiae parochialis in villa Wąsosz die 4 novembris 1799 usque ad finem anno 1843, s. 136; AACz., sygn. KM 3543, s. 77.

${ }^{15}$ J. Łaski, Liber beneficiorum archidiecezji gnieźnieńskiej, t. 1, ed. J. Łukowski, Gniezno 1881, s. 528.

${ }^{16}$ ADWł., sygn. AAG Wiz. 8, s. 302.

${ }^{17}$ ADWł., sygn. AAG Wiz. 9, s. 553.

${ }^{18}$ ADWł., sygn. AAG Wiz. 13, k. 190v.

${ }^{19}$ ADWł., sygn. AAG Wiz. 17, k. 34.

${ }^{20}$ ADWł., sygn. AAG Wiz. 59, s. 1164.

${ }^{21}$ ADWł., sygn. AAG Wiz. 73, s. 318. 
Pustkowiami nazywano osady powstające najczęściej w lasach, w miejscu lub obok samotnych zakładów przemysłowych, głównie hut żelaza lub szkła. Niekiedy początek nowym osadom dawali smolarze lub popielarze, zakładając na wykarczowanych terenach pola uprawne. Zakładano również tzw. coloniae, czyli pojedyncze gospodarstwa dające często początek większym osadom ${ }^{22}$. Informacje o nich odnotowywali skrupulatnie wizytatorzy w aktach kościelnych z XVIII w. ${ }^{23}$ Nowe osady zakładano przeważnie na piaszczystych i bagiennych terenach dawnych puszcz ${ }^{24}$.

Kilka osad, zwanych pustkowiami, założono na terenie parafii Wąsosz już w pierwszej połowie XVIII w. wzdłuż rzek Warta i Liswarta oraz przy traktach komunikacyjnych. Powstały one na obrzeżach ówczesnych terenów uprawnych. Najwięcej informacji o osadach, określanych mianem pustkowie lub colonia pochodzi z zachowanych w parafii Wąsosz ksiąg metrykalnych. Odnotowywano w nich chrzty, śluby i pogrzeby osób je zamieszkujących. Ich nazwy mają często swoją genezę w przydomkach i nazwiskach pierwszych ich mieszkańców lub w wykonywanych przez nich zajęciach. W najstarszej zachowanej księdze metrykalnej parafii Wąsosz z lat 1743-1799 wymieniono Antonie (1738 r.), Koty (1740 r.), Kule (1737 r.), Pustkowie Wąsoskie (1748 r.) i Smolarze (1748 r., także jako Smolarze Więckowskie). Kolejne osady pojawiły się w następnych dziesięcioleciach tego stulecia. Na kartach księgi ochrzczonych odnotowano Brzóski (1771 r.), Bugaj (1771 r., także jako Pustkowie Więckowskie), Kamienna (1781 r., także jako Kamienne Wąsoskie), Lelity (1773 r., także jako Lelito Pustkowie Więckowskie), Łyki (1745 r., także jako Łyki Pustkowie Wąsoskie), Mele (1778 r., także jako Mele Popowskie), Płaczki (1769 r.), Gryglaki (1772 r., także jako Grygle Popowskie), Pustkowie Popowskie (1769), Smolarze Popowskie (1793), Szczera (1797, także jako Szczery Popowskie), Świtały (1744 r.) i Wróże (1770 r., także jako Wróże Popowskie) ${ }^{25}$.

W XIX w. nastąpił dalszy rozwój osadnictwa na terenie parafii Wąsosz. Dawne pustkowia rozrastały się do wielkości dużych wiosek lub zostawały wchłonięte przez okoliczne miejscowości. Na mapie topograficznej Królestwa Polskiego, do której pomiary terenów parafii Wąsosz przeprowadzono przed 1831 r., wymieniono: Wąsosz, Więcki, Popów, Pustkowie Lelity, Pustkowie Antonie, Pustkowie Płaczki, Pustkowie Kamionna, Pustkowie Kule, Pustkowie Koty,

${ }^{22}$ W. Rusiński, W dobie upadku gospodarczego (1655-1793), [w:] Dzieje wsi wielkopolskiej, red. W. Rusiński, Poznań 1959, s. 73-74; tenże, Rozwój gospodarczy ziem polskich w zarysie, Warszawa 1963, s. 113-114; tenże, Gospodarka w dobie regresu, [w:] Dzieje Wielkopolski, t. 1: Do roku 1793, red. J. Topolski, Poznań 1979, s. 714-716.

${ }^{23}$ Np. ADWł., sygn. AAG Wiz. 18; sygn. AAG Wiz. 56; sygn. AAG Wiz. 59.

${ }^{24}$ Okres do 1795 r., oprac. A. Wyczański, C. Kuklo, [w:] Historia Polski w liczbach. Ludność. Terytorium, red. A. Jezierski, Warszawa 1994, s. 38-39.

${ }^{25}$ AACz., sygn. KM 1151. 
Pustkowie Wróże, Pustkowie Łyki, Pustkowie Mele, Pustkowie Zawady, Smolarze i folwark Kąty ${ }^{26}$.

Wizytujący w 1836 r. parafię Wąsosz dziekan krzepicki, ks. Antoni Szymański, wymienił w aktach z nazwy jednak tylko cztery największe miejscowości. Zapisał, że były:

wieś Wąsosz z przyległemi pustkowiami, wieś Popów podobnież z pustkowiami, wieś Więcki podobnież z pustkowiami, pustkowie Zawady ${ }^{27}$.

W katalogu diecezji włocławskiej wydanym na rok 1878, poza trzema największymi wsiami: Wąsoszem, Więckami i Popowem, zapisano, że do parafii należała także Nowa Wieś i pustkowia: Brzózki, Zawady, Smolarze, Dąbrowa, Lelity, Antonie, Płaczki oraz folwark Kąty ${ }^{28}$. W następnych dziesięcioleciach nastąpił dalszy rozwój osadnictwa na terenie parafii. W 1920 r. do parafii należały wsie: Wąsosz Poduchowny (część wsi przy kościele), Wąsosz (górna kolonia), Wąsosz (kolonia za dawnym dworem, czyli dzisiejszy Wąsosz Dolny), Nowa Wieś i Kule (obie nad Liswartą), Brzózki (nad Liswartą), Zawady (za Liswartą), Popów (dwór koło kaplicy), już wtedy rozparcelowany, Zborowy (sic! dzisiejsze Zbory), Popów (kolonia średnia), Popów (kolonia Dębiana) czyli dzisiejsze Dębie, Popów kolonia Dąbrówka), Smolarze, Wrzosy, Dąbrowa, Lelity, Annolesie, Marianów, Kąty, Więcki, Antonie i Płaczki (nad Wartą) $)^{29}$.

W 1931 r. wymieniono w schematyzmie diecezji częstochowskiej następujące miejscowości w parafii: Wąsosz Poduchowny, Wąsosz Górny, Wąsosz (kolonia), Brzózki, Popów, Dąbrówka, Popów (zapewne Popów Parcele), Zawady, Zbory, Więcki, Dąbrowa, Annolesie, Marianów, Kąty (folwark), Płaczki, Antonie, Lelity i Smolarze. Pominięto jednak Kule, Nową Wieś, Dębie i Wrzosy ${ }^{30}$.

Po erygowaniu w 1953 r. w Popowie ekspozytury, a potem w 1957 r. parafii, wydzielono do nowej placówki wsie: Dąbrowa, Smolarze, Wrzosy, Dębie, Popów, Zbory, Zawady i Dąbrówka. W parafii Wąsosz pozostały: Wąsosz Poduchowny, Wąsosz Górny, Wąsosz Dolny, Wąsosz Parcela, Kule, Nowa Wieś, Brzózki, Marianów, Annolesie, Więcki, Płaczki, Antonie i Lelity ${ }^{31}$.

26 http://www.mapywig.org/m/Polish_maps/series/126K_Mapa_Kwatermistrzostwa/CP-12_Kol _II_Sek_VI_Wielu\%C5\%84_Radomsko.jpg (dostęp - 22.04.2015 r.).

${ }^{27} \mathrm{AACz}$., sygn. Księgi Dziekańskie (dalej: KD) 15, s. 24.

${ }^{28}$ Catalogus ecclesiarum et utriusque cleri tam saecularis quam regularis dioecesis vladislaviensis seu calissiensis pro anno Domini 1879, [w:] Ordo divini offici ad usum dioecesis vladislaviensis seu calisiensis pro anno Domini 1879, Varsaviae 1878, s. 80.

${ }^{29}$ APWąsosz, brak sygn. Liber Visitarum Episcopalium Ecclesiae Parochialis in villa Wąsosz, s. 59-60.

${ }^{30}$ Schematismus universi venerabilis cleri saecuralis et regularis dioecesis Częstochoviensis pro Anno Domini 1931, Częstochoviae 1931, s. 69.

${ }^{31}$ APWąsosz, brak sygn. Liber Visitarum Episcopalium Ecclesiae Parochialis in villa Wąsosz, s. 92. 
W kolejnych latach połączono administracyjnie Wąsosz Poduchowny, Wąsosz Górny i Wąsosz Parcele w jedną miejscowość o nazwie Wąsosz Górny. Aktualnie w wąsoskiej parafii są miejscowości: Wąsosz Górny, Wąsosz Dolny, Annolesie, Antonie, Brzózki, Kule, Marianów, Lelity, Nowa Wieś, Płaczki, Trzebca i Więcki ${ }^{32}$.

\section{Miejscowości z XIX i XX w.}

W XIX w. założono kolejne osady na terenie parafii Wąsosz. Część z nich powstało na wykarczowanych terenach wokół dwóch wsi: Popowa i Więcek. Niektóre wsie utworzono na drodze administracyjnej łącząc dawne pustkowia w jedną miejscowość lub dzieląc dotychczasowy areał uprawny.

Osadę Węgry Popowskie wspomniano po raz pierwszy 17 lipca 1803 r. przy okazji chrztu Rozalii, córki Dominika Węgier i Ewy Urbaniaczki ${ }^{33}$. Zapewne w późniejszym czasie osada została przyłączona do Popowa lub innej pobliskiej miejscowości.

Pod datą 5 września 1852 r. pojawiła się w aktach metrykalnych osada Posada Leśna Wąsosz. Wspomniano o niej przy okazji chrztu Julii Justyny, córki Teodora Puacza i Anny z Urbańskich ${ }^{34}$. Możliwe, że był to obszar dzisiejszej leśniczówki położonej między Wąsoszem a Popowem.

Po powstaniu styczniowym pojawiła się w dokumentach miejscowość Nowa Wieś, określana także jako Wąsoska. Pierwsza wzmianka o niej w księgach metrykalnych pochodzi z 28 czerwca 1868 r. Odnotowano wtedy chrzest Petroneli, córki Karola Kuli i Zuzanny z Kubaników ${ }^{35}$. Zapewne w skład Nowej Wsi, utworzonej na drodze administracyjnej, weszły pustkowia położone wzdłuż Liswarty, m.in. Grygle, Koty, Kule, Łyki i Wróże. W 1886 i 1893 r. zanotowano, że była to kolonia i karczma nad Liswartą. Miejscowość liczyła wtedy 33 domy, w tym jedną karczmę, i miała 230 mieszkańców. Obejmowała 1361 mórg, w tym 583 morgi areału uprawnego ${ }^{36}$.

Miejscowość Dąbrowa, wzmiankowana jako Kolonia Dąbrowa, pojawiła się w źródłach parafialnych po raz pierwszy 2 października 1876 r. przy okazji chrztu Michała, syna Marcina Melki i Agnieszki z Krychów ${ }^{37}$. W lutym 1877 r. odnotowano ją już jako Dąbrowę przy okazji chrztu Józefa, syna Karola Antczaka

\footnotetext{
${ }^{32}$ Archidiecezja Częstochowska. Katalog 2005, red. J. Mielczarek, M. Mikołajczyk, Częstochowa 2006, s. 439.

${ }^{33}$ APWąsosz, brak sygn. Liber metrices baptisatorum Ecclesiae parochialis in villa Wąsosz die 4 novembris 1799 usque ad finem anno 1843, s. 27.

${ }^{34}$ APWąsosz, brak sygn. Liber metrices baptisatorum ab anno 1844, s. 76.

${ }^{35}$ Tamże, s. 199.

${ }^{36}$ Nowa Wieś, [w:] Stownik geograficzny Królestwa Polskiego..., t. 7, red. F. Sulimierski, B. Chlebowski, W. Walewski, Warszawa 1886, s. 201; Wasosz, s. 177.

${ }^{37}$ APWąsosz, brak sygn., Liber metrices baptisatorum ab anno 1844, s. 255.
} 
i Katarzyny z Kosmałów ${ }^{38}$. W 1880 r. określano ją jako Dąbrowę Więckowską, wspominając, że była pustkowiem ${ }^{39}$. Osada powstała na wykarczowanych terenach na południowy zachód od Więcek w kierunku Smolarzy.

W styczniu 1875 r. w źródłach pojawiła się osada określana jako Nowy Folwark. Wspomniano o niej przy okazji chrztu Walentego, syna Jana Pietruchy i Joanny z Bognerów ${ }^{40}$. Prawdopodobnie był to folwark Kąty wzmiankowany już ok. 1831 r. na mapie z tego czasu. Przy nim powstała osada, która wzięła od niego swoją nazwę. Kąty wspomniano 25 marca 1877 r. przy okazji chrztu Marianny, nieślubnej córki Klary Strugacz ${ }^{41}$. Nazwa występowała jeszcze w $1944 \mathrm{r}^{42}$ i funkcjonowała w świadomości starszych mieszkańców do końca XX w.

Nazwa Wąsosz Kolonia pojawiała się w księgach parafialnych po raz pierwszy 4/16 października 1892 r. ${ }^{43}$ Odnotowano wtedy chrzest córki Ignacego Idzikowskiego i Łucji z Banaszkiewiczów, Jadwigi ${ }^{4}$. W późniejszym okresie zmieniono nazwę miejscowości na Wąsosz Dolny. Pod tą nazwą figuruje na mapie z $1934 \mathrm{r}^{45}$

Zbory, jako część Popowa, w księgach metrykalnych pojawiły się 17/29 maja 1892 r. Odnotowano wtedy chrzest syna Adama Nowaka, któremu nadano imię Antoni ${ }^{46}$. Ponownie wymieniono tę nazwę pod datą 4/17 czerwca $1900 \mathrm{r}$. kiedy odnotowano urodziny Piotra, syna Wojciecha Rysia i Teofilii z Kubanów i Macjanny, córki Józefa Ceglarka i Marianny z Grajów ${ }^{47}$. Prawdopodobnie jest to dzisiejsza miejscowość o tej samej nazwie.

Osadę Marianów wymieniono w aktach parafialnych pierwszy raz jako Kolonię Marianów 10/22 sierpnia 1897 r. przy okazji odnotowania urodzin Stefanii, córki Józefa Strugacza i Marianny z Sobotów ${ }^{48}$. Osada powstała przy dawnym folwarku Kąty. W kolejnych latach rozrosła się do wielkości dużej wsi. Według lokalnej tradycji, swoją nazwę wywodzi od imienia jednej z córek właściciela folwarku Kąty, Marii.

${ }^{38}$ Tamże, s. 257.

${ }^{39}$ Dąbrowa Więckowska, [w:] Stownik geograficzny Królestwa Polskiego..., t. 1, red. F. Sulimierski, B. Chlebowski, W. Walewski, Warszawa 1880, s. 920.

${ }^{40}$ APWąsosz, brak sygn. Liber metrices baptisatorum ab anno 1844, s. 245.

${ }^{41}$ Tamże, s. 258.

42 http://www.mapywig.org/m/WIG_maps/series/025K_german/4428_G_Rebielice-Szlacheckie _XI.1944.jpg (dostęp - 27.04.2015).

${ }^{43}$ Pierwszą datę podawano według kalendarza juliańskiego a drugą według kalendarza gregoriańskiego.

${ }^{44}$ AACz., sygn. KM 3557, k. 86v, nr 91/1892.

45 http://www.mapywig.org/m/WIG_maps/series/100K/P44_S28_DZIALOSZYN.jpg (dostęp -22.04 .2015 r.).

${ }^{46}$ AACz., sygn. KM 3557, k. 74v, nr 43/1892.

${ }^{47}$ AACz., sygn. KM 3558, k. 102, nr 80/1900, nr 81/1900.

${ }^{48}$ Tamże, k. 30v, nr 94/1897. 
Procesy osadnicze nie zakończyły się na terenie parafii Wąsosz w XIX w. W XX w. odnotowano powstanie kolejnych nowych miejscowości. Niektóre $\mathrm{z}$ nich wydzielono $\mathrm{z}$ innych wsi, do których były wliczane. Inne rozwinęły się wokół istniejących w lasach pojedynczych siedzib.

Jako osadę wspomniano po raz pierwszy Wrzosy 16/29 listopada 1902 r. przy okazji urodzin Andrzeja, syna Walentego Randoka (zapewne Randaka) i Teofili z Jędrysiaków ${ }^{49}$. Ponownie nazwa pojawiła się 20 lipca/2 sierpnia 1904 r., kiedy odnotowano urodziny kolejnego ich syna, Andrzeja ${ }^{50}$ i 15/28 grudnia 1904 r. przy urodzinach Julianny, córki Pawła Chabirka i Marianny z Chałupków ${ }^{51}$.

Dębie jako wieś pod nazwą zu Popow uwidoczniono na mapie z 1910 r. W 1920 r. określono ją mianem Popów (kolonia Dębina). Jednak jako Dębie występuje dopiero na mapie z $1934 \mathrm{r}^{52}$

Miejscowość Annolesie jako samodzielną osadę wyodrębniono zapewne dopiero w okresie międzywojennym. Wspomniano o niej w $1920 \mathrm{r}$. Na mapie z 1934 r. występuje osada pod tą nazwą ${ }^{53}$. Według lokalnej tradycji, swoją nazwę zawdzięcza córce właściciela folwarku Kąty, Annie.

W okresie międzywojennym część Popowa zaczęto określać nazwą Dąbrówka. Początkowo była znana jako Popów (kolonia Dąbrówka). W schematyzmie z 1931 r. i na mapie z 1934 r. widnieje jako samodzielna miejscowość ${ }^{54}$.

W okresie międzywojennym jako samodzielna osada pojawiła się miejscowość Feliksów. Uwidoczniono ją na mapie z 1934 r. ${ }^{55}$ Jednak w świadomości okolicznych mieszkańców była znana jako Huby ${ }^{56}$. Po II wojnie światowej włączono ją administracyjnie do Więcek.

Po I wojnie światowej rozparcelowano majątek ziemski w Wąsoszu. Na działkach zaczęli w latach 20. XX w. budować swoje domostwa ich właściciele,

\footnotetext{
${ }^{49}$ AACz., sygn. KM 3557, k. 167v, nr 133/1902.

${ }^{50}$ Tamże, k. 212v, nr 83/1904.

${ }^{51}$ Tamże, k. 223, nr 147/1906.

${ }^{52}$ APWąsosz, brak sygn. Liber Visitarum Episcopalium Ecclesiae Parochialis in villa Wąsosz, s. 59; http://www.mapywig.org/m/WIG_maps/series/100K/P44_S28_DZIALOSZYN.jpg (dostęp -22.04 .2015 r.).

${ }^{53}$ APWąsosz, brak sygn. Liber Visitarum Episcopalium Ecclesiae Parochialis in villa Wąsosz, s. 59; http://www.mapywig.org/m/WIG_maps/series/100K/P44_S28_DZIALOSZYN.jpg (dostęp -22.04 .2015 r.).

${ }^{54}$ Schematismus universi venerabilis cleri..., s. 69; http://www.mapywig.org/m/WIG_maps/ series/100K/ P44_S28_DZIALOSZYN.jpg (dostęp - 22.04.2015 r.).

55 http://www.mapywig.org/m/WIG_maps/series/100K/P44_S28_DZIALOSZYN.jpg (dostęp -22.04 .2015 r.).

${ }^{56}$ A. Brückner, Stownik etymologiczny języka polskiego, Warszawa 1970, s. 173. Nazwa Huby pochodzi zapewne z niemieckiego die Hufe - łan, włóka.
} 
dając początek miejscowości Wąsosz Parcele ${ }^{57}$. Nazwa ta jest używana przez okolicznych mieszkańców do dziś, choć oficjalnie stanowi współcześnie część Wąsosza Górnego.

\section{Mieszkańcy}

Mieszkańcy terenów nadwarciańskich trudnili się w minionych wiekach głównie uprawą roli. Aż do 1864 r. większość z nich była ludnością poddańczą i zobowiązaną do pańszczyzny. Jeszcze do potopu szwedzkiego (1655-1660) w królewszczyźnie Wąsosz było kilka rodzin wolnych kmieci. Jednak częste wojny, przemarsze wojsk i zarazy prowadziły do zubożenia wsi, a także do zmian w składzie społeczno-zawodowym oraz wyznaniowym i etnicznym ludności. Po zniszczeniach wojennych z połowy XVII w. kształtowała się także nowa struktura społeczno-gospodarcza $\mathrm{wsi}^{58}$.

Po potopie szwedzkim przybywało na wsi chłopów małorolnych i bezrolnych. Wśród małorolnych wyróżniano zagrodników, nazywanych także ogrodnikami, i chałupników. Zagrodnicy uprawiali niewielkie działki roli lub siedzieli tylko na zagrodach. W pierwszym przypadku mieli do uprawy do około ćwierci włóki ${ }^{59}$, w drugim ich gospodarstwo obejmowało tylko zagrodę i niewielki ogród. Największe ogrody miały nawet do 1 ha powierzchni, jednak przeciętnie ok. $1 / 4-1 / 2$ ha ${ }^{60}$. Bezrolnych mieszkańców wsi dzielono na komorników i czeladź. Komornicy mieszkali komora u bogatszych gospodarzy lub w osobnych, najczęściej dwurodzinnych, dwojakach i nie posiadali własnych gospodarstw. Na komornym siedziały najczęściej żony służących dworskich i wdowy po nich, kobiety samotne, a także wdowy po zagrodnikach, chałupnikach i rzemieślnikach. Zdarzało się, że

57 http://www.mapywig.org/m/WIG_maps/series/100K/P44_S28_DZIALOSZYN.jpg (dostęp $-22.04 .2015 \mathrm{r}$.).

${ }^{58}$ W. Rusiński, $W$ dobie upadku gospodarczego..., s. 75, tenże, Straty i zniszczenia w czasie wojny szwedzkiej oraz jej skutki na obszarze Wielkopolski, [w:] Polska w okresie drugiej wojny pótnocnej, t. 2: Rozprawy, red. K. Lepszy, Warszawa 1957, s. 296; tenże, Rozwój gospodarczy ziem polskich w zarysie, Warszawa 1963, s. 116; B. Baranowski, Gospodarstwo chłopskie i folwarczne we wschodniej Wielkopolsce w XVIII wieku, Warszawa 1958, s. 48; J. Topolski, Zmiany w strukturze wewnętrznej (spolecznej i gospodarczej) wsi oraz folwarku, [w:] Zarys historii gospodarstwa wiejskiego w Polsce, t. 2, red. J. Leskiewiczowa, Warszawa 1964, s. 79; L. Żytkowicz, Okres gospodarki folwarczno-pańszczyźnianej, [w:] Historia chłopów polskich, t. 1: Do upadku Rzeczypospolitej, red. S. Inglot, Warszawa 1970, s. 293-295; tenże, Nastęstwa ekonomiczne i społeczne niskich plonów zbóż w Polsce od połowy XVI do połowy XVIII wieku, „Roczniki Dziejów Społecznych i Gospodarczych”, t. 34, 1973, s. 6.

${ }^{59}$ A. Dunin-Wąsowicz, Pomiary gruntu w Koronie w XVI-XVIII wieku, Warszawa 1994, s. 71. Włóka - staropolska miara powierzchni rolnej, ok. 17-18 ha.

${ }^{60}$ W. Rusiński, $W$ dobie upadku gospodarczego..., s. 87; Z. Libiszowska, Gospodarstwo wiejskie w Polsce w XVII w. w opinii cudzoziemców, „Kwartalnik Historii Kultury Materialnej”, t. 8, 1960, nr 3, s. 285. 
byli na komorze różnego rodzaju ludzie wędrowni, wolni od poddaństwa. Ci na ogół nie przebywali jednak zbyt długo w jednym miejscu ${ }^{61}$.

Poza ludnością pracującą na roli na wsi mieszkali także rzemieślnicy. Szczególną pozycję zajmowali wśród nich młynarze i karczmarze. Młynarze często byli ludźmi wolnymi. Płacili stały czynsz pieniężny i czasem stawali się ludźmi dość zamożnymi. Jeśli nawet młynarz był poddanym, to jego sytuacja była dużo lepsza niż innych chłopów pańszczyźnianych. Karczmarze zajmowali się wyszynkiem trunków i najczęściej byli zwolnieni z niektórych powinności na rzecz dworu. Od drugiej połowy XVII w. coraz częściej karczmarzami byli Żydzi. Ich liczba ciągle wzrastała ${ }^{62}$.

Na terenie parafii Wąsosz w minionych wiekach budowano młyny na Warcie i Liswarcie oraz Kocince. W 1460 r. wspomniano młynarza Jana Kozika ${ }^{63}$. W latach 1564-1565 w Wąsoszu mieszkali także karczmarze i garncarze, a w okolicy były dwa młyny, jeden na Warcie, a drugi na Kocince, prawym dopływie Liswarty ${ }^{64}$. W aktach lustracji z lat 1616-1620 wymieniono m.in. trzech karczmarzy i młynarza Lyczko (Łyczko) pracującego w młynie na rzece Krzepickiej, czyli na Liswarcie ${ }^{65}$. W czasie potopu szwedzkiego spalono młyn, którego już nie odbudowano. Miejscowość wyludniła się w wyniku wojennych spustoszeń i pojawili się nowi mieszkańcy, m.in. zagrodnicy garncarzy, chałupnicy i kowal ${ }^{66}$.

Przedrozbiorowa struktura społeczna wsi przetrwała w zaborze rosyjskim do uwłaszczenia chłopów w 1864 r. Zlikwidowano wtedy pańszczyznę i nadano ziemię chłopom. Zaczęli oni pracować na własny rachunek na obrabianych gruntach. Nastąpiły wtedy kolejne zmiany w składzie społecznym mieszkańców parafii. W księgach parafialnych pojawiły się określenia: gospodarz, wyrobnik, komornik świadczące o statusie społecznym osób tak nazywanych ${ }^{67}$. Duży przyrost naturalny prowadził do ubożenia rodzin i dzielenia gospodarstw między potomków. Część z nich musiała opuszczać rodzinne miejscowości w poszukiwaniu pracy.

${ }^{61}$ W. Dworzaczek, Studia na dziejami społeczeństwa, polityki i kultury dawnej Polski w wiekach XVI-XVIII, wybór, oprac., bibliografia i posłowie Z. Chodyła, Z. Sprys, Warszawa 2010, s. 152; W. Rusiński, W dobie upadku gospodarczego..., s. 77; B. Baranowski, Gospodarstwo chłopskie..., s. 49-51; A. Wyczański, Geneza i rozwój gospodarki folwarczno-pańszczyźnianej, [w:] Zarys historii gospodarstwa wiejskiego w Polsce, t. 2, red. J. Leskiewiczowa, Warszawa 1964, s. 47-49; J. Topolski, Zmiany w strukturze..., s. 79; L. Żytkowicz, Okres gospodarki..., s. 295-296, 304-305.

${ }^{62}$ W. Rusiński, W dobie upadku gospodarczego..., s. 78-79; A. Wyczański, Geneza i rozwój gospodarki..., s. 50-51; L. Żytkowicz, Okres gospodarki..., s. 303-304.

${ }^{63}$ ADWł., sygn. AAG.A.Kons. Wiel. 1(1460), k. 67v.

${ }^{64}$ Lustracja województw wielkopolskich i kujawskich 1564-1565, cz. 2, wyd. A. Tomczak, Bydgoszcz 1963, s. 82.

${ }^{65}$ Lustracja województw wielkopolskich i kujawskich 1616-1620, cz. 1, wyd. Z. Górski, R. Kabaciński, J. Pakulski, Wrocław-Warszawa-Kraków 1994, s. 174-175.

${ }^{66}$ Lustracja województw wielkopolskich i kujawskich 1659-1665, cz. 2: Województwa sieradzkie, łęczyckie, brzesko-kujawskie i ziemia dobrzyńska, wydali Z. Górski, J. Pakulski, A. Tomczak, Toruń 1996, s. 48.

${ }^{67}$ AACz., sygn. KM 3555. 
W okresie międzywojennym dość popularnym krokiem wśród mieszkańców parafii Wąsosz był wyjazd za granicę w poszukiwaniu pracy. Popularne były wyjazdy sezonowe do prac polowych na terenie Republiki Weimarskiej, później nazwanej III Rzeszą, czyli do Niemiec. Część opuszczała rodzinne strony na stałe osiedlając się m.in. we Francji, a nawet odległej Australii.

Po II wojnie światowej wielu parafian wyjechało na tzw. zachód, czyli ziemie zachodnie osiedlając się tam na stałe. W okresie Polski Ludowej wraz z rozwojem przemysłu i usług część mieszkańców parafii wyjechała do miast i tam znalazła zatrudnienie. W 1955 r. ks. Franciszek Bar, ówczesny proboszcz pisał, że

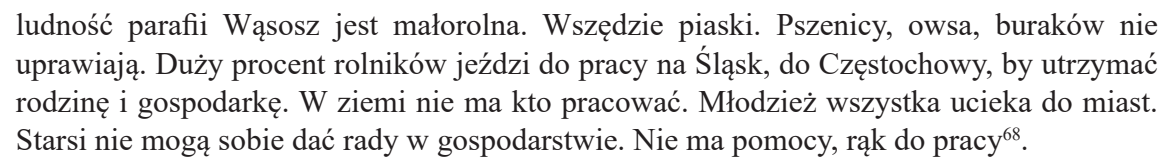

Podobne spostrzeżenia odnotował w kwestionariuszu przed wizytacją biskupią, ks. Wincenty Kowalczyk, dziekan siemkowicki, w 1968 r. Wielu młodych po ślubie wyjeżdżało za pracą do miast i tam się osiedlało. Było to powszechne zjawisko, a we wsiach pozostawali starsi ludzie ${ }^{69}$. Parafia pod względem wiekowym zaczęła się starzeć. Widać to szczególnie na przykładzie liczby dzieci przystępujących do I Komunii świętej i liczby urodzeń oraz zgonów. W 1984 r. było 37 dzieci pierwszokomunijnych, a w 2007 r. tylko $20^{70}$.

Po II wojnie światowej zmieniała się także struktura społeczno-zawodowa mieszkańców. Duża grupa dojeżdżała do okolicznych zakładów pracy, m.in. cementowni „Warta” koło Działoszyna, huty i fabryk włókienniczych w Częstochowie. Powoli parafia Wąsosz z parafii typowo rolniczej stawała się parafią w znacznej mierze chłoporobotników ${ }^{71}$.

W ciągu wieków zmieniała się także struktura etniczna i religijna mieszkańców wsi należących do parafii Wąsosz. Przez długi okres zamieszkiwali te tereny wyłącznie Polacy-katolicy. Od połowy XVIII w. na terenie parafii zaczęli osiedlać się także Żydzi. Żydowscy karczmarze pojawili się najpierw Więckach ok. 1763 r. ${ }^{72} \mathrm{~W}$ ciągu następnych stuleci populacja Żydów wzrosła do kilku rodzin. Żydzi zajmowali się głównie handlem. W latach 20. XX w. w parafii mieszkały tylko dwie rodziny żydowskie w Więckach. Wcześniej zapewne było ich więcej, ale reszta wyniosła się do miast, jak pisał ówczesny proboszcz, ks. Bolesław

${ }^{68}$ APWąsosz, brak sygn. Liber Visitarum Episcopalium Ecclesiae Parochialis in villa Wąsosz, s. 95.

${ }^{69}$ APWąsosz, brak sygn. Liber Visitarum Episcopalium Ecclesiae Parochialis in villa Wąsosz, s. 121.

${ }^{70}$ APWąsosz, brak sygn. Kwestionariusz do kanonicznej wizytacji parafii [1981], s. 19; brak sygn. Nota statystyczna za rok 1984, s. 1; brak sygn. Nota statystyczna za rok 2007, s. 5.

${ }^{71}$ APWąsosz, brak sygn. Kwestionariusz do kanonicznej wizytacji parafii [1981], s. 19; brak sygn. Nota statystyczna za rok 1985, s. 1; brak sygn. Kwestionariusz kanonicznej wizytacji parafii w archidiecezji częstochowskiej [2007], s. 1.

${ }^{72}$ ADWł., sygn. AAG Wiz. 59, s. 1167-1168. 
Choroszyński ${ }^{73}$. W czasie II wojny światowej Żydzi z Więcek zostali wywiezieni i wymordowani przez niemieckich okupantów.

W XIX w. na teren parafii pojawili się osadnicy o korzeniach niemieckich. Zakładali oni nowe gospodarstwa i szybko się polonizowali. Wielu z nich należało do pierwszych mieszkańców Dąbrowy i pochodziło zapewne z terenów pruskiego wówczas Śląska ${ }^{74}$. W XX w. pojawili się na terenie parafii także przedstawiciele różnych wyznań niekatolickich ${ }^{75}$.

\section{Od poddanych plebańskich do Wąsosza Poduchownego}

Grupą zasługującą na szczególną uwagę wśród mieszkańców parafii Wąsosz są poddani plebańscy, którzy dali początek części wsi określanej do dziś jako Wąsosz Poduchowny. Proboszczowie w Wąsoszu osadzali ich w pobliżu kościoła na gruntach należących do parafii. W zamian za niewielkie działki ziemi oddane im w użytkowanie pracowali na rzecz proboszcza. Ta grupa ludności w Wąsoszu istniała do uwłaszczenia w 1864 r. Pierwsze wzmianki o nich pochodzą z pierwszej połowy XVI w. Wspomniano wtedy o karczmarzu plebańskim Tomaszu Smoczek i zagrodniku Macieju Smarza ${ }^{76}$ W 1636 r. na gruntach plebańskich było już osadzonych pięciu zagrodników i trzech garncarzy oraz karczmarz ${ }^{77}$. Na początku lat 60. XVIII w. wspomniano o sześciu zagrodnikach osiadłych na gruntach plebańskich. Byli nimi: Szymon Zawodniak, Jakub Chamarka, Tomasz Głuch, Tomasz Raskowy, Mikołaj Zarowny i Szymon Dziura. Pracowali oni po dwa dni piesze w tygodniu na ziemi plebańskiej. Mieli domy z innymi budynkami gospodarskimi i kawałki ziemi wydzielone $\mathrm{z}$ gruntów plebańskich. Wymieniono wtedy także dwóch przybyszów osadzonych na ziemi plebańskiej: Jana Marusek i Wojciecha Kowalczyka oraz trzy kobiety: Reginę Maychrowkę, Mariannę Maychawidkę i Barbarę Stachową. Pracowali oni po jednym dniu w tygodniu pieszo na ziemi plebańskiej i mieli tylko małe ogrody ${ }^{78}$. W 1779 r. zapisano w aktach wizytacji, że na ziemi plebańskiej było siedmiu poddanych, którzy mieli role i ogrody wydzielone z gruntów plebańskich. Pracowali oni po dwa dni w tygodniu ${ }^{79}$. W 1797 r. na ziemi plebańskiej było sześciu poddanych. Z nich dwóch: Jan Zawodziński i Jan Dziura, pracowało po dwa dni pieszo w tygodniu. Pozostali czterej pracowali po

\footnotetext{
${ }^{73}$ APWąsosz, brak sygn. Liber Visitarum Episcopalium Ecclesiae Parochialis in villa Wąsosz, s. 79.

${ }^{74}$ APWąsosz, brak sygn. Liber metrices baptisatorum Ecclesiae parochialis in villa Wąsosz die 4 novembris 1799 usque ad finem anno 1843; brak sygn. Liber metrices baptisatorum ab anno 1844; AACz., sygn. 3543; sygn. KM 3550; sygn. KM 3555. Do dziś w Dąbrowie i innych miejscowościach mieszkają ich potomkowie, nie wiedząc często o swoich niemieckich korzeniach.

${ }^{75}$ APWąsosz, brak sygn. Liber Visitarum Episcopalium Ecclesiae Parochialis in villa Wąsosz, s. 122.

${ }^{76}$ J. Łaski, Liber beneficiorum archidiecezji gnieźnieńskiej, t. 1, ed. J. Łukowski, Gniezno 1881, s. 528.

${ }^{77}$ ADWł., sygn. AAG. Wiz. 5, s. 98.

${ }^{78}$ ADWł., sygn. AAG Wiz. 59, s. 1165.

${ }^{79}$ ADWł., sygn. AAG. Wiz. 73, s. 324.
} 
jednym dniu i nie byli poddanymi gruntowymi. Byli oni ludźmi wolnymi i mogli opuścić ziemię plebańską po wywiązaniu się z ciążących na nich zobowiązañ ${ }^{80}$.

Proboszczowie w Wąsoszu utrzymywali swoich poddanych także w XIX w., gdyż nie skonfiskowano im ziemi parafialnej w okresie pruskiego panowania na tym terenie (1793-1807). W 1830 r. zapisano, że na ziemi plebańskiej mieszkali i pracowali włościanie plebańscy. Było na niej wtedy dziewięć domów z różnymi niewielkimi budynkami gospodarczymi. W jednym z nich mieszkał organista i komornik. W drugim domu mieszkały komornice, w trzecim Piotr Dura, w czwartym Łukasz Szymczykowski, w piątym Andrzej Zawodziński, w szóstym Franciszek Kozieł. Ósmy dom zamieszkiwał Marceli Prukacz, a ostatni Maciej Dura. Wszyscy poddani, z wyjątkiem komornic, mieli swoje rodziny ${ }^{81}$.

Po powstaniu styczniowym, ukazem carskim z 14/26 grudnia 1865 r., rosyjskie władze zaborcze pozbawiły instytucje kościelne, w tym parafie, wszelkich nieruchomości ziemskich i kapitałów, a duchownych także prawa pobierania dziesięcin. Argumentowano to tym, że duchownym przyznano wtedy stałe pensje. Parafiom, poza gruntami, na których znajdowały się budowle sakralne i budynki plebańskie oraz wewnątrz ogrodzeń kościelnych i cmentarnych, pozostawiono tylko sześć mórg ziemi, czyli ok. 3 ha. Resztę ziemi przejęto na rzecz państwa. Ziemię plebańską i budynki zajmowane przez włościan plebańskich na mocy ukazu uwłaszczeniowego z 19 lutego / 2 marca 1864 r. przeszły na ich własność $^{82}$. Parafię w Wąsoszu pozbawiono więc nieruchomości, z wyjątkiem gruntów wspomnianych w ukazie. Ostatecznie bezrolnych włościan w Wąsoszu uwłaszczono zapewne po ukazie carskim z 21 sierpnia / 2 września 1866 r. zabraną ziemią kościelną i być może częścią dóbr rządowych. Wtedy także część ziemi w Wąsoszu nadano zdymisjonowanym żołnierzom, którzy jednak sprzedali swoje działki. Miały one po osiem mórg powierzchni. Na tym obszarze powstała część wsi Wąsosz, która do dziś określa się zwyczajowo jako Wąsosz Poduchowny ${ }^{83}$.

\section{Zakończenie}

Dzieje osadnictwa i mieszkańców miejscowości położonych w widłach Warty i Liswarty, należących do parafii Wąsosz, wpisują się w ramy przemian zachodzących na ziemiach polskich od średniowiecza aż do czasów współczesnych. Po znacznym wzroście liczby osad i ludności w XVIII i XIX w. oraz pierwszej

${ }^{80}$ ADWł., sygn. AAG Wiz. 93, s. 173-174.

${ }^{81}$ AACz., sygn. KD 15, s. 78-79.

${ }^{82}$ Dziennik Praw Królestwa Polskiego, t. 63, Warszawa 1865, s. 374-377, 390-391; B. Kumor, Ustrój i organizacja Kościoła polskiego w okresie niewoli narodowej (1772-1918), Kraków 1980, s. 695.

${ }^{83}$ Dziennik Praw Królestwa Polskiego, t. 66, s. 63; APWąsosz, Liber Visitarum Episcopalium Ecclesiae Parochialis in villa Wąsosz, s. 66, 68. 
połowie XX w. nastąpił po II wojnie światowej regres demograficzny, który nadal się pogłębia. Miejscowości wyludniają się i starzeją. Zmieniła się także struktura zawodowa mieszkańców, którzy przez wiele stuleci utrzymywali się głównie z uprawy roli. Współcześnie wielu z nich znajduje zatrudnienie w pobliskich zakładach produkcyjnych i usługach.

Rev. Stawomir Zabraniak

THE HISTORY OF SETTLEMENT AT THE CONFLUENCE OF THE WARTA AND LISWARTA RIVERS AND POPULATION CHANGE FOR EXAMPLE THE PARISH OF WĄSOSZ

Areas situated between rivers Warta and Liswarta at their confluence (part of these lands used to cover the parish of Wąsosz in the past) attracted many settlers, especially in the $18^{\text {th }}$ and $19^{\text {th }}$ Century. Around three villages: Wąsosz, Więcki and Popów in the $18^{\text {th }}$ Century arose eighteen minor settlements, next seven in the $19^{\text {th }}$ Century and five at the beginning of the $20^{\text {th }}$ Century.

Inhabitants of these areas were mainly peasants, farmers. In the $16^{\text {th }}$ and $17^{\text {th }}$ Century some of them have been working as potters and millers. After the second world war took place a demographic transition. Many people, especially young, left their homes and moved to the "Recovered Territories" (incorporated to Poland according to the Potsdam Agreement) or towns and cities elsewhere. Some farmers had to work also as laborers in factories - mainly in Częstochowa, Działoszyn and Kłobuck. Political transformation in the nineties of the $20^{\text {th }}$ Century resulted in radical social changes also among inhabitants living at the Warta River. An industrial crisis and unprofitability of agricultural production nowadays results in substantial unemployment and demographic regression. 